\title{
THE SENSITIVITY OF BRUCELLA ABORTUS TO CHEMOTHERAPEUTIC AGENTS
}

\author{
L. Robertson, I. D. Farrell and P. M. HinchlifFe \\ Public Health Laboratory, Royal Infirmary, Meadow Street, Preston PR1 6PS
}

\begin{abstract}
MANY chemotherapeutic agents have been tried in the treatment of both acute and chronic brucellosis. It is generally accepted that tetracycline is the treatment of choice, but Spink (1964) suggested that in the more severe infections the simultaneous administration of streptomycin might be beneficial. Evidence for the synergistic action of tetracycline and streptomycin is incomplete, and most reports have been based on the treatment of small groups of patients. The role of ampicillin requires clarification, because in-vitro studies indicate that brucellae are sensitive to concentrations within the therapeutic range (Agius and Mifsud, 1962; Robinson, 1966, cited by McDevitt, 1970), although the clinical studies of Farid, Bassily and Omar (1967) and McDevitt (1970) suggest that the drug is of little value in treatment.

The main purpose of this investigation was to determine the sensitivity of strains of Brucella abortus to ampicillin, tetracycline and streptomycin by four different quantitative techniques. The sensitivity to carbenicillin, gentamicin, kanamycin and co-trimoxazole (a combination of sulphamethoxazole and trimethoprim) was also investigated.
\end{abstract}

\section{MATERIALS AND METHODS}

Strains of B. abortus. Twenty-five strains comprised five strains each of biotypes 1, 2, 4, 5, and 9; all were recent isolates from human or bovine sources. The strains were maintained on serum-dextrose (SD) agar slopes ( 5 per cent. horse serum, 1 per cent. dextrose) and kept at $4^{\circ} \mathrm{C}$. When required, they were subcultured onto 5 per cent. blood agar and incubated for 3 days at $37^{\circ} \mathrm{C}$. Throughout this study, all cultures were incubated in air containing 10 per cent. $\mathrm{CO}_{2}$.

Sensitivity tests. Sensitivity to ampicillin, streptomycin and tetracycline was tested by the following methods: broth dilution (BD), agar dilution-heavy inoculum (ADHI), agar dilution-light inoculum (ADLI) and ditch. The strains were tested with carbenicillin, gentamicin and kanamycin by the ADHI and ditch methods.

The possible synergistic effect of sulphamethoxazole and trimethoprim and of tetracycline and streptomycin was investigated. As a preliminary screening procedure, one strain of each biotype was seeded on to a SD plate in which two ditches had been cut at right angles; each ditch had been filled with agar containing one of the pair of substances under test. Evidence of synergism was investigated further by the ADHI method. Lysed horse blood ( 5 per cent.) was added to the medium as recommended by Darrell, Garrod and Waterworth (1968) when sulphamethoxazole and trimethoprim were used.

BD method. A 3-day serum-dextrose (SD) broth culture (Alton and Jones, 1967) of each strain was diluted 1 in 10 in sterile phosphate-buffered saline pH 7.2 (PBS). Two-fold dilutions of each antibiotic in SD broth were prepared and distributed in 2-ml amounts in sterile tubes. 
The ranges of final concentrations were ampicillin 16 to $0.25 \mu \mathrm{g}$ per $\mathrm{ml}$, tetracycline 1.6 to $0.025 \mu \mathrm{g}$ per $\mathrm{ml}$, and streptomycin 6.4 to $0.1 \mu \mathrm{g}$ per $\mathrm{ml}$. One drop of the diluted culture was added to each antibiotic dilution and also to control tubes, and incubation was for $72 \mathrm{hr}$ at $37^{\circ} \mathrm{C}$. The minimum inhibitory concentration (MIC) was taken as the lowest concentration of antibiotic required to give complete inhibition as judged by the turbidity of the broth. A volume of $0.2 \mathrm{ml}$ from each tube showing complete inhibition was subcultured in SD broth.

ADHI method. A suspension of organisms, comparable to a Brown's opacity tube no. 2, was prepared in sterile PBS and further diluted 1 in 10. A series of two-fold dilutions of antibiotic in sterile PBS was incorporated into SD agar at a temperature of $48-50^{\circ} \mathrm{C}$ in a ratio of one part antibiotic solution to 19 parts of medium. The ranges of final concentrations were ampicillin 32 to $0.25 \mu \mathrm{g}$ per ml, streptomycin $12: 8$ to $0.1 \mu \mathrm{g}$ per ml, and tetracycline 1.6 to 0.025 $\mu \mathrm{g}$ per $\mathrm{ml}$. Use of a Lidwell phage-typing applicator permitted the simultaneous inoculation of suspensions of 25 strains of $B$. abortus. The plates were incubated at $37^{\circ} \mathrm{C}$ for $72 \mathrm{hr}$. The MIC was taken as the lowest concentration of antibiotic giving complete inhibition of growth.

ADLI method. A 3-day SD broth culture of each strain was diluted in sterile PBS to give approximately 4000 organisms per $\mathrm{ml}$. The medium was that used in the ADHI method. The antibiotic plates were inoculated with $0.04 \mathrm{ml}$ of the suspension (approximately 160 organisms), which was distributed over the plate with a glass spreader. The plates were incubated at $37^{\circ} \mathrm{C}$ for $72 \mathrm{hr}$. The MIC was taken as the lowest concentration that gave complete inhibition of growth.

Ditch method. The inoculum was that used in the ADHI method. SD agar was poured into $90 \mathrm{~mm}$-diameter, flat-bottomed, plastic petri dishes to a depth of approximately $6 \mathrm{~mm}$, and a $15 \mathrm{~mm}$-wide strip of agar was removed along the diameter of each plate. The central ditch so formed was filled with SD agar containing the appropriate concentration of antibiotic. A series of two-fold dilutions of antibiotic in sterile PBS was incorporated into SD agar at a temperature of $48-50^{\circ} \mathrm{C}$ in a ratio of one part antibiotic solution to 19 parts of medium. The molten antibiotic-SD agar was used to fill the central ditch. The ranges of final concentrations were ampicillin $32 \mu \mathrm{g}$ per $\mathrm{ml}$ to $2 \mu \mathrm{g}$ per ml, streptomycin $10 \mu \mathrm{g}$ per $\mathrm{ml}$ to $0.6 \mu \mathrm{g}$ per $\mathrm{ml}$, and tetracycline $16 \mu \mathrm{g}$ per ml to $1 \mu \mathrm{g}$ per ml. A loopful of the suspension of each strain was streaked across the plate at right angles to the central ditch. Each plate was inoculated with six strains together with a similar suspension of the WHO prototype strain of B. abortus, biotype 2 , which was used as a standard control. The sizes of the zones of inhibition were measured in millimetres.

The MIC of each antibiotic for the standard strain had been determined with the ADHI method. The MIC for the test strains by the ditch method was calculated as follows (Farrell, 1969).

MIC of test strain (ditch method) $=$ MIC of standard strain (ADHI method) $\times$ sensitivity factor.

Sensitivity factor $=\frac{\mathrm{Ct}}{\mathrm{Cs}} ; \mathrm{Ct}=$ concentration of antibiotic required to inhibit the growth of the test strain over the width of the ditch only; $\mathrm{Cs}=$ concentration of antibiotic required to inhibit the growth of the standard strain over the width of the ditch only.

The relationship between the concentration of antibiotic in the ditch and the size of the zone of inhibition was established with the standard strain. There was a linear relationship between the log of the concentration of antibiotic in the ditch and the size of the zone of inhibition. This relationship was described by a regression equation for each antibiotic, and it was assumed that the gradient of the regression lines was constant for each antibiotic irrespective of the brucella strain tested, because, when all tests were performed simultaneously under similar conditions, it depended only on the rate of diffusion of antibiotic. From the zone sizes recorded with the series of ditch plates for each antibiotic, the antibiotic concentration $\mathrm{Ct}$ was calculated by reference to the appropriate regression equation for each of the test strains. For most strains, more than one of the set of ditch plates for a particular antibiotic gave a zone of inhibition and consequently a mean value for $\mathrm{Ct}$ was obtained. 


\section{RESULTS}

\section{Sensitivity of 25 strains of Brucella abortus to six antibiotics}

The MIC of ampicillin, streptomycin and tetracycline obtained by four different methods are shown in table I. The BD and ditch methods gave comparable results, whereas higher values were obtained by the ADLI and ADHI methods, particularly the latter.

The sensitivity of biotypes $1,2,4,5$ and 9 to the same three antibiotics, measured by the four different methods, are shown in table II as the mean MIC

TABLE I

Sensitivity of 25 strains of Brucella abortus to tetracycline, streptomycin and ampicillin as determined by four methods

\begin{tabular}{|c|c|c|c|c|c|c|c|c|c|c|c|c|c|c|c|c|}
\hline \multirow{3}{*}{ Method* } & \multicolumn{15}{|c|}{ Number of strains sensitive to } & \\
\hline & \multicolumn{4}{|c|}{$\begin{array}{l}\text { tetracycline } \\
\text { at the MIC } \\
(\mu \mathrm{g} \text { per } \mathrm{ml}) \text { of }\end{array}$} & \multicolumn{7}{|c|}{$\begin{array}{l}\text { streptomycin } \\
\text { at the MIC } \\
(\mu \mathrm{g} \text { per ml) of }\end{array}$} & \multicolumn{5}{|c|}{$\begin{array}{l}\text { ampicillin } \\
\text { at the MIC } \\
(\mu \mathrm{g} \text { per } \mathrm{ml}) \text { of }\end{array}$} \\
\hline & 0.1 & 0.2 & 0.4 & 0.8 & 0.2 & 0.4 & 0.8 & 1.6 & $3 \cdot 2$ & 6.4 & 12.8 & 1 & 2 & 4 & 8 & 16 \\
\hline $\begin{array}{l}\text { BD } \\
\text { ADHI } \\
\text { ADLI } \\
\text { Ditch }\end{array}$ & $\begin{array}{l}3 \\
0 \\
1 \\
6\end{array}$ & $\begin{array}{r}12 \\
0 \\
3 \\
4\end{array}$ & $\begin{array}{r}4 \\
7 \\
8 \\
15\end{array}$ & $\begin{array}{r}6 \\
18 \\
13 \\
0\end{array}$ & $\begin{array}{l}1 \\
0 \\
0 \\
3\end{array}$ & $\begin{array}{r}5 \\
0 \\
0 \\
13\end{array}$ & $\begin{array}{l}5 \\
1 \\
7 \\
7\end{array}$ & $\begin{array}{r}10 \\
4 \\
6 \\
2\end{array}$ & $\begin{array}{r}4 \\
16 \\
10 \\
0\end{array}$ & $\begin{array}{l}0 \\
3 \\
2 \\
0\end{array}$ & $\begin{array}{l}0 \\
1 \\
0 \\
0\end{array}$ & $\begin{array}{l}1 \\
4 \\
5 \\
3\end{array}$ & $\begin{array}{r}5 \\
3 \\
16 \\
4\end{array}$ & $\begin{array}{l}6 \\
1 \\
0 \\
0\end{array}$ & $\begin{array}{r}13 \\
8 \\
4 \\
1\end{array}$ & $\begin{array}{r}0 \\
9 \\
0 \\
17\end{array}$ \\
\hline
\end{tabular}

* See text.

values. The strains of biotype 4 included four classical strains and one aberrant, dye-sensitive strain (Farrell and Robertson, 1967). The ADHI method gave the highest mean MIC, with three exceptions, although the differences between the methods were rarely greater than two-fold for any particular strain. For each of the three antibiotics, there was little difference between the sensitivities of biotypes 1, 4, 5 and 9, except for the dye-sensitive strain of biotype 4 . This strain, and those of biotype 2 , were noticeably more sensitive.

In the BD tests, all tubes in which growth was inhibited were subcultured into SD broth and then onto SD agar. Organisms were recovered from concentrations of ampicillin ten times greater than the MIC but not from dilutions of streptomycin or tetracycline containing more than the MIC.

Table III shows that the MIC values of gentamicin, kanamycin and carbenicillin obtained by the ADHI method were higher than those obtained by the ditch method.

The distribution of the MIC of the six antibiotics between strains is shown in the figure. The ADHI results were used, because all the strains were inoculated simultaneously onto each antibiotic plate, thus reducing the effects of variations in operative procedure and composition of the medium. The MIC values of gentamicin and kanamycin were within the range 1 to $2 \mu \mathrm{g}$ per $\mathrm{ml}$ and 2 to $4 \mu \mathrm{g}$ 
per $\mathrm{ml}$ respectively, but the MIC of streptomycin fell within the wider range of 0.8 to $12.8 \mu \mathrm{g}$ per $\mathrm{ml}$. The strains were almost uniformly sensitive to tetracycline,

TABLE II

The mean minimum inhibitory concentration (MIC) values of tetracycline, streptomycin and ampicillin, for the major biotypes of Brucella abortus when tested by four methods

\begin{tabular}{|c|c|c|c|c|}
\hline \multirow{2}{*}{ Biotype* } & \multirow{2}{*}{ Method $†$} & \multicolumn{3}{|c|}{ MIC values ( $\mu \mathrm{g}$ per $\mathrm{ml})$ for } \\
\hline & & tetracycline & streptomycin & ampicillin \\
\hline 1 & $\begin{array}{l}\text { BD } \\
\text { ADHI } \\
\text { ADLI } \\
\text { Ditch }\end{array}$ & $\begin{array}{l}0.4 \\
0.8 \\
0.7 \\
0.4\end{array}$ & $\begin{array}{l}0.9 \\
3 \cdot 2 \\
2.1 \\
0.6\end{array}$ & $\begin{array}{r}6.4 \\
9.6 \\
3.2 \\
>10\end{array}$ \\
\hline 2 & $\begin{array}{l}\text { BD } \\
\text { ADHI } \\
\text { ADLI } \\
\text { Ditch }\end{array}$ & $\begin{array}{l}0.2 \\
0.4 \\
0.2 \\
0.1\end{array}$ & $\begin{array}{l}0.4 \\
1.4 \\
0.8 \\
0.3\end{array}$ & $\begin{array}{l}1.4 \\
1.4 \\
1.0 \\
1.0\end{array}$ \\
\hline 4 & $\begin{array}{l}\text { BD } \\
\text { ADHI } \\
\text { ADLI } \\
\text { Ditch }\end{array}$ & $\begin{array}{l}0.4 \\
0.9 \\
0.6 \\
0.2\end{array}$ & $\begin{array}{l}1.6 \\
3.2 \\
1.4 \\
0.5\end{array}$ & $\begin{array}{r}4.2 \\
5.6 \\
2.0 \\
>10\end{array}$ \\
\hline 5 & $\begin{array}{l}\text { BD } \\
\text { ADHI } \\
\text { ADLI } \\
\text { Ditch }\end{array}$ & $\begin{array}{l}0.5 \\
0.8 \\
0.6 \\
0.3\end{array}$ & $\begin{array}{l}1.9 \\
6.4 \\
3.8 \\
0.6\end{array}$ & $\begin{array}{r}5.8 \\
14.4 \\
3 \cdot 2 \\
>10\end{array}$ \\
\hline 9 & $\begin{array}{l}\text { BD } \\
\text { ADHI } \\
\text { ADLI } \\
\text { Ditch }\end{array}$ & $\begin{array}{l}0.4 \\
0.7 \\
0.8 \\
0.3\end{array}$ & $\begin{array}{l}1.9 \\
3 \cdot 8 \\
3 \cdot 8 \\
0.9\end{array}$ & $\begin{array}{r}4.5 \\
13.0 \\
4.4 \\
\geqq 10\end{array}$ \\
\hline
\end{tabular}

- Five strains of each biotype tested by each of the four methods. † See text.

TABLE III

Sensitivity of 25 strains of Brucella abortus to gentamicin, kanamycin and carbenicillin as determined by two methods

\begin{tabular}{|c|c|c|c|c|c|c|c|c|c|c|c|c|c|c|c|c|c|}
\hline \multirow{3}{*}{ Method } & \multicolumn{17}{|c|}{ Number of strains sensitive to } \\
\hline & \multicolumn{4}{|c|}{$\begin{array}{l}\text { gentamicin } \\
\text { at the MIC } \\
(\mu \mathrm{g} \text { per } \mathrm{ml}) \text { of }\end{array}$} & \multicolumn{5}{|c|}{$\begin{array}{l}\text { kanamycin } \\
\text { at the MIC } \\
(\mu \mathrm{g} \text { per } \mathrm{ml}) \text { of }\end{array}$} & \multicolumn{8}{|c|}{$\begin{array}{l}\text { carbenicillin } \\
\text { at the MIC } \\
(\mu \mathrm{g} \text { per } \mathrm{ml}) \text { of }\end{array}$} \\
\hline & 0.25 & 0.5 & 1.0 & 2 & 0.25 & 0.5 & 1.0 & 2.0 & 4.0 & 0.5 & 1 & 2 & 4 & 8 & 16 & 32 & 64 \\
\hline $\begin{array}{l}\text { ADHI } \\
\text { Ditch }\end{array}$ & $\begin{array}{l}0 \\
6\end{array}$ & $\begin{array}{r}0 \\
19\end{array}$ & $\begin{array}{l}5 \\
0\end{array}$ & $\begin{array}{r}20 \\
0\end{array}$ & $\begin{array}{l}0 \\
1\end{array}$ & $\begin{array}{l}0 \\
6\end{array}$ & $\begin{array}{r}0 \\
18\end{array}$ & $\begin{array}{l}5 \\
0\end{array}$ & $\begin{array}{r}20 \\
0\end{array}$ & $\begin{array}{l}0 \\
5\end{array}$ & $\begin{array}{l}0 \\
2\end{array}$ & $\begin{array}{l}2 \\
0\end{array}$ & $\begin{array}{l}3 \\
0\end{array}$ & $\begin{array}{l}\mathbf{0} \\
\mathbf{0}\end{array}$ & $\begin{array}{c}2 \\
18^{*}\end{array}$ & $\begin{array}{c}8 \\
\ldots\end{array}$ & $\begin{array}{l}10 \\
\ldots\end{array}$ \\
\hline
\end{tabular}

* Greater than or equal to $16 \mu \mathrm{g}$ per $\mathrm{ml}$ of carbenicillin.

all being inhibited by $0.8 \mu \mathrm{g}$ per $\mathrm{ml}$, and a few, including strains of biotype 2 , by $0.4 \mu \mathrm{g}$ per $\mathrm{ml}$. 


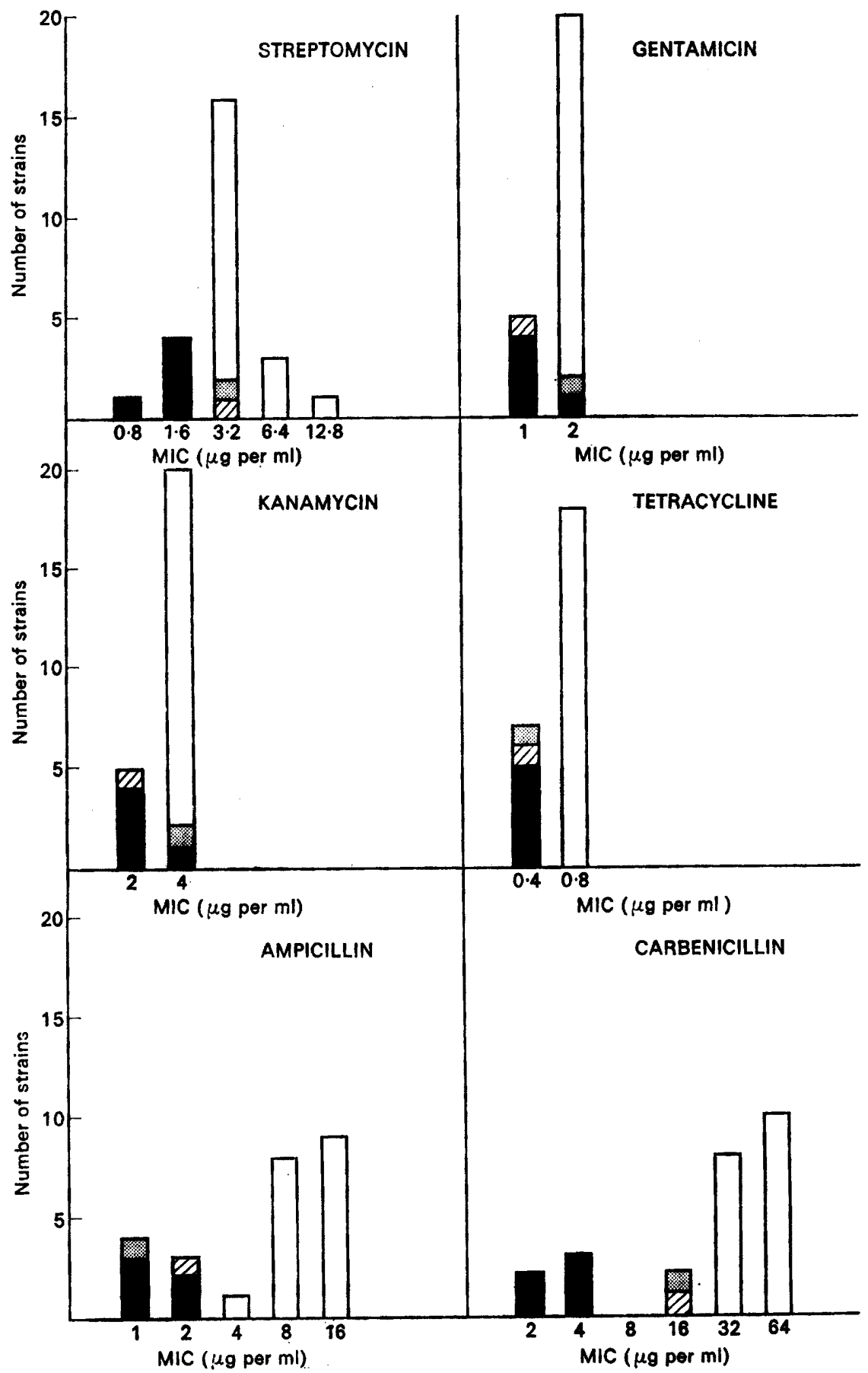

FIGURE.-The distribution of the minimum inhibitory concentration (MIC) values of streptomycin, gentamicin, kanamycin, tetracycline, ampicillin and carbenicillin for 25 strains of Brucella abortus; $\square=$ strains of biotype $2 ; \square=$ dye-sensitive biotype 4 ; $=$ antibiotic sensitive strain of biotype 9; $\square=$ other strains of biotypes $1,4,5$, and 9 . 
The distribution of the MIC of the semisynthetic penicillins was quite different. The MIC of ampicillin and carbenicillin fell within the wide ranges 1 to $16 \mu \mathrm{g}$ per $\mathrm{ml}$ and 2 to $64 \mu \mathrm{g}$ per $\mathrm{ml}$ respectively. There was a bimodal distribution of the MIC of both ampicillin and carbenicillin; strains of biotype 2 were sensitive to $2 \mu \mathrm{g}$ per $\mathrm{ml}$ or less of ampicillin and either 2 or $4 \mu \mathrm{g}$ per $\mathrm{ml}$ of carbenicillin, whereas the MIC of the majority of other strains was $8 \mu \mathrm{g}$ per $\mathrm{ml}$ or greater for ampicillin and $32 \mu \mathrm{g}$ per $\mathrm{ml}$ or greater for carbenicillin.

Two strains were of particular interest, their pattern of antibiotic sensitivity being unlike that of the other strains of their biotype. The high sensitivity of dye-sensitive strains of biotype 4 has been previously described by Farrell and Robertson (1967), but it is evident from the figure that one strain of biotype 9 was similarly sensitive although it had the normal dye-sensitivity pattern.

\section{Investigation of synergism}

A synergistic effect between tetracycline and streptomycin was not apparent, but synergism between sulphamethoxazole and trimethoprim was demonstrated. The ADHI method showed that for all 25 B. abortus strains the MIC of sulphamethoxazole was $2 \mu \mathrm{g}$ per $\mathrm{ml}$ and of trimethoprim $32 \mu \mathrm{g}$ per $\mathrm{ml}$. When the two agents were used in combination in the same ratio as their MIC values, a 16-fold potentiation between them was evident, all strains being inhibited by a combination of $0.125 \mu \mathrm{g}$ per ml of sulphamethoxazole and $2 \mu \mathrm{g}$ per ml of trimethoprim.

\section{Discussion}

The methods used for the determination of antibiotic sensitivity have generally been developed for organisms growing more rapidly than brucellae, which require 72 hours' incubation to produce visible growth. In our preliminary experiments the disk-diffusion method was found to give much larger zones of inhibition than would be expected with organisms of similar sensitivity that produce visible growth within $24 \mathrm{hr}$. For each " antibiotic" there was a close correlation between the zone sizes and the MIC values for the various strains when all tests were set up at the same time on the same batch of media. However, variations from test to test occurred in the sizes of zones, particularly those produced by the semi-synthetic penicillins, sulphamethoxazole, and trimethoprim. Consequently, we do not recommend the disk-diffusion method for routine sensitivity testing of brucella strains. Any differences between the results given by the four methods used in this investigation were probably attributable to differences in the size of the inoculum. The MIC values obtained by the ADHI methods were often higher than those found by the three other methods. The ditch method, when calibrated with a strain of known sensitivity, was satisfactory for determining the MIC of chemotherapeutic agents for brucellae, and is particularly useful for large numbers of strains.

Brucellosis in both its acute and chronic form is essentially a disease of intracellular parasitism. In acute cases, recovery usually occurs within $6 \mathrm{mth}$ or at most $1 \mathrm{yr}$, but some untreated cases become chronic and persist for years. The insidious onset and variable manifestations of human brucellosis 
make diagnosis difficult. Consequently, the evaluation of treatment is difficult, and this may be why so many different therapeutic agents have been used (Spink, 1956; Roux and Renoux, 1951).

In making comparisons between the MIC values and the levels of antibiotics attainable in plasma, it should be remembered that $B$. abortus is an intracellular organism. The peak plasma levels and plasma half-lives of six antibiotics used in the study have been given by Bryant (1968), Bunn (1970), Cox (1970), Martin (1970), Ory (1970), O'Grady et al. (1971) and Garrod and O'Grady (1971). The peak plasma level of tetracycline has been given as $3 \mu \mathrm{g}$ per $\mathrm{ml}$. Of 25 strains of B. abortus, 18 were inhibited by $0.8 \mu \mathrm{g}$ per ml and seven by $0.4 \mu \mathrm{g}$ per $\mathrm{ml}$. Tetracycline is generally considered to be bacteristatic but in broth-dilution titrations it was bactericidal to $B$. abortus, although we feel this requires further investigation. The in-vitro sensitivity to tetracycline supports the results of animal experiments (Heilman, 1949; Magoffin, Anderson and Spink, 1949; Braude and Spink, 1950) and treatment of human brucellosis (Spink, 1956; Rizzo-Naudi, Griscti-Soler and Ganado, 1967). Spink (1956) reported on the treatment of 67 cases of brucellosis due mainly to $B$. abortus with $0.5 \mathrm{~g}$ of tetracycline four times a day for 10-21 days. Forty-eight patients recovered promptly after the initial course and 11 of 19 patients who relapsed responded to a further course of tetracycline. Rizzo-Naudi, Griscti-Soler and Ganado (1967) reported comparable findings in treating $400 \mathrm{~B}$. melitensis infections with tetracycline.

A synergistic action between tetracycline and streptomycin was demonstrated in mice by Heilman, and this combination was used in the treatment of human infections by Herrell and Barber (1949). Further observations were made by Shaffer, Kucera and Spink (1953), but we are not aware of satisfactory proof of this synergism in the treatment of human brucellosis, although Richardson and Holt (1962), who used infected bovine cells, found that tetracycline and streptomycin in combination are bactericidal whereas either antibiotic alone is only bacteristatic to intracellular brucellae.

The peak plasma level of streptomycin has been given as 25 to $30 \mu \mathrm{g}$ per ml. Of our 25 strains, 21 were inhibited by $3.2 \mu \mathrm{g}$ per ml although a concentration of $12.8 \mu \mathrm{g}$ per $\mathrm{ml}$ was required to inhibit all of the remaining strains. Suter (1952) and Mackaness and Smith (1953) have shown that the intracellular penetration of streptomycin is poor, and it is generally accepted that streptomycin alone is not effective in the treatment of brucellosis, although it is still widely used in combination with tetracycline.

All 25 strains were inhibited by $2 \mu \mathrm{g}$ per ml gentamicin, and five were inhibited by $1 \mu \mathrm{g}$ per $\mathrm{ml}$; the same five strains were inhibited by $2 \mu \mathrm{g}$ per $\mathrm{ml}$ kanamycin and the remainder by $4 \mu \mathrm{g}$ per $\mathrm{ml}$. The peak plasma levels of gentamicin and kanamycin have been given as 5 to $10 \mu \mathrm{g}$ per $\mathrm{ml}$ and $30 \mu \mathrm{g}$ per $\mathrm{ml}$ respectively, and their plasma half-lives (150 and $300 \mathrm{~min}$., respectively) suggest that either antibiotic may be more effective than streptomycin in combination with tetracycline.

Farid, Bassily and Omar (1967) treated B. melitensis infection with ampicillin, but of seven patients five remained bacteriaemic at the end of treatment. McDevitt (1970) considered that ampicillin was valueless in the treatment of 
chronic brucellosis. These observations are in accord with our findings that, not only were the MIC values of ampicillin for strains other than of biotype 2 in excess of peak plasma levels of 4-5 $\mu \mathrm{g}$ per $\mathrm{ml}$ but also the antibiotic was bacteristatic only. Sensitivity to carbenicillin was no more encouraging.

Co-trimoxazole has been used in the treatment of acute and chronic brucellosis (Lal et al., 1970; Giunchi, de Rosa and Fabiani, 1971; Hassan et al., 1971). The results in acute infections are encouraging, although further clinical trials are necessary. Our investigations confirmed the synergistic effect of sulphonamide and trimethoprim on B. abortus. Darrell, Garrod and Waterworth (1968) found that all bacteria investigated except Neisseria spp were more sensitive to trimethoprim than to sulphonamide on a weight-for-weight basis. Like Neisseria spp, B. abortus was less sensitive to trimethoprim ( $32 \mu \mathrm{g}$ per $\mathrm{ml})$ than to sulphamethoxazole ( $2 \mu \mathrm{g}$ per $\mathrm{ml})$, suggesting that a high level of trimethoprim in the plasma should be maintained. The findings of Drew et al. (1967) suggest that $500 \mathrm{mg}$ trimethoprim daily combined with $1 \mathrm{~g}$ sulphamethoxazole is well tolerated, although in brucellosis the treatment may have to be continued for at least 21 days.

\section{SUMMARY}

The sensitivity of 25 strains of Brucella abortus, comprising strains of the biotypes commonly encountered in the United Kingdom, was determined to six antibiotics and co-trimoxazole (a combination of sulphamethoxasole and trimethoprim) by means of four methods, including a modification of the ditchdiffusion method. The ditch method was shown to be satisfactory for routine sensitivity testing of brucellae. The strains were almost uniformly sensitive to tetracycline, and the MIC values were between four and eight times less than the expected peak plasma levels. The strains were not as sensitive to streptomycin as those previously reported by Spink (1956), and the MIC values to this antibiotic were distributed over a wider range of concentrations than those of gentamicin or kanamycin. A comparison of MIC, peak plasma levels and plasma half-lives suggest that gentamicin and kanamycin may be more effective than streptomycin in the treatment of brucellosis when used in combination with tetracycline.

The failure of ampicillin in the treatment of brucellosis accords with the finding that of 25 strains 17 had MIC values in excess of the peak plasma levels. An experiment with carbenicillin indicated that it was unlikely to be effective in the treatment of $B$. abortus infection.

Synergism between sulphamethoxazole and trimethoprim was demonstrated in vitro on all strains examined. The strains were less sensitive to trimethoprim than sulphamethoxazole, indicating that a high plasma value for trimethoprim should be maintained, but further clinical trials of co-trimoxazole are necessary.

\section{REFERENCES}

Agrus, E., AND Mrfsud, J. 1962. The action of "Penbritin" on Brucella microorganisms. Archs Inst. Pasteur, Tunis, 39, 97.

Alton, G. C., AND JoNes, L. M. 1967. Laboratory techniques in brucellosis. WHO Monographs Series no. 55, Geneva. 
BRAUDE, A. I., AND SPINK, W. W. 1950. The action of aureomycin and other chemotherapeutic agents in experimental brucellosis. J. Immun., 65, 185.

Bryant, M. C. 1968. Antibiotics and their laboratory control. London.

BunN, P. A. 1970. Kanamycin. Med. Clins N. Am., 54, 1245.

Cox, C. E. 1970. Gentamicin. Med. Clins N. Am., 54, 1305.

Darrell, J. H., Garrod, L. P., and Waterworth, Pamela M. 1968. Trimethoprim: laboratory and clinical studies. J. Clin. Path., 21, 202.

Drew, C. D. M., Hughes, D. T. D., Fowle, A. S. E., and Cassell, M. A. 1967. Effective treatment of chronic bronchitis with short term trimethoprim and sulphamethoxazole. Verl. Wien. med. Akad., 1, 293.

FARReLl, I. D. 1969. The use of antibiotics and antibacterial agents for the selective isolation of Brucella abortus. Ph.D. Thesis, University of Liverpool.

FARRell, I. D., AND RoBertson, L. (1967). The sensitivity of biotypes of Brucella abortus to three antibiotics used in selective media, and the description of a new biotype. J. Hyg., Camb., 65, 165.

FARID, Z., BASSILY, S., AND OMAR, M. S .1967. Ampicillin ("Penbritin ") in the treatment of acute Brucella melitensis septicaemia and Salmonella typhi urinary carriers. J. Trop. Med. Hyg., $20,95$.

GarRod, L. P., AND O'Grady, F. (1971). Antibiotics and chemotherapy, 3rd ed., Edinburgh and London, p. 70.

GIUNCHI, G., DE ROSA, F., AND FABIANI, F. (1971). Trimethoprim-sulphamethoxazole combination in the treatment of acute human brucellosis. Chemotherapy, 16, 332.

Hassan, A., Erian, M. M., FarID, Z., Hathout, S. D., and Sorensen, K. 1971. Trimethoprim-sulphamethoxazole in acute brucellosis. Br. Med. J., 3, 159.

HeILman, F. R. 1949. The effect of combined treatment with aureomycin and dihydrostreptomycin on brucella infection in mice. Proc. Staff. Meet. Mayo Clin., 24, 133.

Herrell, W. E., AND BARBER, T. E. 1949. The combined use of aureomycin and dihydrostreptomycin in the treatment of brucellosis. Proc. Staff. Meet. Mayo Clin., 24, 138.

Lal, S., Modwal, K. K., Fowle, A. S. E., Peach, B., and Popham, R. D. 1970. Acute brucellosis treated with trimethoprim and sulphamethoxazole. Br. Med. J., 3, 256.

MACKANESS, G. V., AND SMITH, N. 1953. The bactericidal action of isoniazid, streptomycin and tetracycline on extracellular and intracellular tubercle bacilli. Am. Rev. Tuberc., $67,322$.

MAGOFFIN, R., ANDERSON, D., AND SpINK, W. W. (1949). Therapy of experimental brucella infection in the developing chick embryo. IV. Therapy with aureomycin. J. Immun., $62,125$.

Martin, N. J. 1970. The present status of streptomycin in antimicrobial therapy. Med. Clins N. Am., 54, 1161.

MCDevitT, D. G. 1970. Ampicillin in the treatment of brucellosis: a controlled therapeutic trial. Br. J. Ind. Med., $27,67$.

O'Grady, F., Brown, W. R. L., Gaya, H., and Mackintosh, I. P. 1971. Antibiotic levels on continuous intravenous infusion. Lancet, $2,209$.

Ory, E. M. 1970. The tetracyclines. Med. Clins N. Am., 54, 1173.

Richardson, M., AND Holt, J. N. 1962. Synergistic action of streptomycin with other antibiotics on intracellular Brucella abortus in vitro. J. Bact., 84, 638.

Rizzo-NaUdi, J., Griscti-Soler, N., AND GaNado, W. 1967. Human brucellosis: an evaluation of antibiotics in the treatment of brucellosis. Post-grad. Med. J., 43, 520.

Roux, J., AND Renoux, G. 1951. Action de l'association chloramphenicol aureomycin sur les Brucella in vitro. C. r. Séanc. Soc. Biol., 145, 264.

Shaffer, J. M., KUCERA, C. J., AND SPINK, W. W. 1953. Evaluation of prolonged antibiotic therapy in mice with chronic brucella infection due to Brucella melitensis. J. Immun., 70, 31 .

SPINK, W. W. 1956. The nature of brucellosis. Minneapolis, p. 216.

SPINK, W. W. 1964. Host-parasite relationship in brucellosis. Lancet, 2, 161.

SUTER, F. 1952. Multiplication of tubercle bacilli within phagocytes cultivated in vitro, and effect of streptomycin and isonicotinic acid hydrazide. Am. Rev. Tuberc., 65, 775. 